\title{
People living with AIDS: Association between nursing diagnoses and sociodemographic/clinical characteristics
}

\author{
Pessoas vivendo com Aids: associação entre diagnósticos de enfermagem e \\ características sociodemográficas/clínicas \\ Personas que viven con el SIDA: asociación entre los diagnósticos de enfermería y \\ características sociodemográficas/clínicas
}

\section{Richardson Augusto Rosendo da Silva', Romanniny Hévillyn Silva Costa', Laísi Catharina da Silva Barbalho Braz', Indira de Araújo Lucena', Kalyane da Silva Ferreira', Fernando Hiago da Silva Duarte'}

'Universidade Federal do Rio Grande do Norte. Natal, Rio Grande do Norte, Brazil.

How to cite this article:

Silva RAR, Costa RHS, Braz LCSB, Lucena IA, Ferreira KSF, Duarte FHS. People People living with AIDS:

Association between nursing diagnoses and sociodemographic/clinical characteristics.

Rev Bras Enferm [Internet]. 2018;71(5):2535-42. DOI: http://dx.doi.org/10.1590/0034-7167-2017-0420

Submission: 06-15-2017 Approval: 11-05-2017

\begin{abstract}
Objective: To analyze the association between nursing diagnoses and sociodemographic and clinical characteristics in people living with AIDS. Method: Cross-sectional study with 100 people living with AIDS in a University Hospital. Data collection took place between January and July 2015, using an interview script and physical examination. The association occurred through Pearson's Chi-Square Test and Fisher's Exact Test. Results: The most prevalent nursing diagnoses were: ineffective protection, poor knowledge, lack of adherence and sexual dysfunction. Significant associations were observed among nursing diagnoses with the following sociodemographic and clinical characteristics: marital status, place of residence, level of schooling, family income, modes of transmission of acquired immunodeficiency virus, current opportunistic infection, abandonment of treatment, difficulty of access to health services and use of alcohol and illicit drugs. Conclusion: The diagnoses presented significant associations with sociodemographic and clinical aspects.

Descriptors: Nursing; Nursing Diagnosis; Nursing Processes; Nursing Care; Acquired Immunodeficiency Syndrome.
\end{abstract}

\section{RESUMO}

Objetivo: Analisar a associação entre os diagnósticos de enfermagem e características sociodemográficas e clínicas em pessoas vivendo com Aids. Método: Estudo transversal realizado com 100 pessoas vivendo com Aids em um Hospital Universitário. A coleta de dados ocorreu entre janeiro e julho de 2015, utilizando-se um roteiro de entrevista e exame físico. A associação ocorreu por meio dos testes qui-quadrado de Pearson e exato de Fisher. Resultados: Os diagnósticos de enfermagem mais prevalentes foram: proteção ineficaz, conhecimento deficiente, falta de adesão e disfunção sexual. Observaram-se associações significantes entre os diagnósticos de enfermagem com as seguintes características sociodemográficas e clínicas: situação conjugal, local de moradia, nível de escolaridade, renda familiar, forma de exposição ao vírus da imunodeficiência adquirida, infecção oportunista atual, abandono de tratamento, dificuldade de acesso ao serviço de saúde e uso de álcool e de drogas ilícitas. Conclusão: Os diagnósticos apresentaram associações significativas com aspectos sociodemográficos e clínicos.

Descritores: Enfermagem; Diagnóstico de Enfermagem; Processos de Enfermagem; Cuidados de Enfermagem; Síndrome de Imunodeficiência Adquirida.

\section{RESUMEN}

Objetivo: Analizar la asociación entre los diagnósticos de enfermería y características sociodemográficas y clínicas en personas que viven con el sida. Método: Estudio transversal realizado con 100 personas que viven con el sida en un Hospital Universitario. La recolección de datos ocurrió entre enero y julio de 2015, utilizando un guion de entrevista y examen físico. La asociación ocurrió por medio de las pruebas chi-cuadradas de Pearson y el exacto de Fisher. Resultados: Los diagnósticos de enfermería 
más prevalentes fueron: protección ineficaz, conocimiento deficiente, falta de adhesión y disfunción sexual. Se observaron asociaciones significativas entre los diagnósticos de enfermería con las siguientes características sociodemográficas y clínicas: situación conyugal, lugar de vivienda, nivel de escolaridad, ingreso familiar, forma de exposición al virus de la inmunodeficiencia adquirida, infección oportunista actual, abandono de tratamiento, dificultad de acceso al servicio de salud y uso de alcohol y de drogas ilícitas. Conclusión: Los diagnósticos presentaron asociaciones significativas con aspectos sociodemográficos y clínicos. Descriptores: Enfermería; Diagnóstico de Enfermería; Procesos de Enfermería; Cuidados de Enfermería; Síndrome de Inmunodeficiencia Adquirida.

CORRESPONDING AUTHOR Richardson Augusto Rosendo da Silva E-mail: rirosendo@yahoo.com.br

\section{INTRODUCTION}

There are 36.7 million people living with the Human Immunodeficiency Virus (HIV) in the world. In Brazil, from 1980 to June 2016, 842,710 cases of Acquired Immune Deficiency Syndrome (AIDS) were registered ${ }^{(1-2)}$.

Although it has invested in public policies and educational campaigns related to AIDS prevention, as well as in diagnostic and treatment exams, more than 41,000 new cases take place every year in the country and there is no drop in new infections ${ }^{(3)}$. Considering the deep inequalities of Brazilian society and the spread of AIDS in the country, this disease reveals itself with an epidemic of several dimensions and different contexts that, over time, undergo significant transformations in its epidemiological profile, being marked today by its feminization, heterosexualization, internalization, aging, low level of schooling and impoverishment ${ }^{(4)}$.

When reflecting on its dissemination, it is necessary that health professionals, especially nurses, care for people living with AIDS, considering the sociodemographic, economic and cultural contexts that involve this disease $\mathrm{e}^{(3-4)}$. Thus, it is essential to understand the responses of the individual to the disease, considering these aspects. It is also understood that evaluating and monitoring clinical characteristics, such as signs and symptoms, are important to base nursing care on a care practice aimed at meeting the individual's real needs $s^{(5)}$.

Nursing Processes (NP) is also considered as an important strategy to support the autonomous and qualified practice of nurses. For the identification of nursing diagnoses (ND), the techniques of interview and physical examination are used, which allow the attainment of the data related to sociodemographic, behavioral and clinical aspects ${ }^{(5-6)}$. Furthermore, the defining characteristics and the related factors/risks of ND can be influenced by sociodemographic and clinical variables. In this sense, associating these variables to a ND becomes useful to determine the clarity and assertiveness of nursing interventions, aiming to achieve positive results that contemplate not only the individual but also the collective ${ }^{(6)}$.

Nursing diagnosis, interventions and results are part of the essential elements of the practice of the nursing personnel as they help in the development of concepts classification systems that participate in the professional language of the area and contribute to the therapeutic judgment of patients about their real care needs including family and community. It is also important to promote sensitivity to expected outcomes through nursing interventions ${ }^{(6)}$.
Thus, to support and justify the development of the study, a search for scientific production was carried out on the association between sociodemographic/clinical characteristics and ND, from January 2012 to December 2016. The search was made in the following electronic databases: American and Caribbean (LILACS), International Literature in Health and Biomedical Sciences (MEDLINE), SCOPUS and CINAHL, using the descriptors: Nursing, Nursing Diagnosis and Nursing Processes. Thus, the deficit of scientific production correlated the sociodemographic and clinical characteristics with the ND in people living with AIDS. The productions found associated these variables only with chronic kidney disease ${ }^{(5-7)}$, justifying the accomplishment of the present study. Given this gap in the literature, the relevance of the study is to analyze the association between the respective characteristics and the ND, so that the nurse tries to dimension assistance not only for the biological needs, but also taking into account the social aspect of people living with AIDS. Therefore, this association can help nurses to plan interventions aimed at the real needs of these people.

In this sense, from this knowledge gap, the following question emerged: is there an association between sociodemographic and clinical characteristics with ND in people living with AIDS? Faced with the concern, the study aimed to analyze the association between nursing diagnoses and sociodemographic and clinical characteristics in people living with AIDS.

\section{OBJECTIVE}

To analyze the association between nursing diagnoses and sociodemographic and clinical characteristics in people living with AIDS.

\section{METHOD}

\section{Ethical aspects}

The ethical precepts of Resolution 466/2012 of the National Health Council of Brazil were respected. The research was approved by the Committee of Ethics in Research with human beings of the Universidade Federal do Rio Grande do Norte, and Certificate of Presentation for Ethical Consideration. All participants signed a Free and Informed Consent Form.

\section{Design, place of study and period}

This is a cross-sectional, descriptive study with a quantitative approach, carried out in a reference HIV/AIDS outpatient clinic, of a University Hospital located in a city in the Northeast of Brazil 
between January and July 2015. The hospital is a reference in infectious and parasitic diseases, and has an outpatient clinic, a testing and counseling center, 10 adult hospitalization wards, an ICU, a day hospital, five pediatric wards and an emergency room.

\section{Population or sampling; inclusion and exclusion criteria}

The sampling of this research was calculated based on the formula developed for studies with finite population and that considers the coefficient of confidence, the sampling error and the size of the population. The following parameters were considered: confidence level of $95 \%(Z \infty=1.96)$, sampling error of $10 \%$ and population of 1,500 people living with AIDS enrolled in the hospital outpatient clinic. We obtained a value of 91 individuals who opted to finish in a total of 100 people living with AIDS, who were selected for convenience, in a consecutive way, by applying the formula.

People living with AIDS who were registered and followed at the outpatient clinic up of the referred hospital, of both genders, having been clinically diagnosed with AIDS for at least one year, aged above 18 years, who did not present any cognitive changes or neurological diseases that made them disable to participate in the interview were considered in the inclusion criteria.

Those who underwent Post-Exposure Prophylaxis (PEP), pregnant women and prisoners were excluded because they were not followed at the outpatient clinic up. People who were taking PEP were excluded because treatment with antiretroviral therapy (ARVT) occurs only for 28 days to avoid the survival and multiplication of HIV in the body, thus avoiding contamination. It is indicated for people who may have had contact with the virus in any situation, such as: sexual violence; unprotected sexual intercourse (without the use of a condom or with condom disruption); occupational accident (with sharp instruments or in direct contact with biological material). In relation to pregnant women, the service only performs the first care and directs them to be followed in the reference maternity hospitals up. For inmates, the outpatient clinic offers the first consultation and follow-up of the treatment is taken by the health team in prisons where they are incarcerated.

\section{Study protocol}

A tool adapted to perform the interview and physical examination was used during the data collection ${ }^{(5)}$. It also addressed sociodemographic, clinical and defining characteristics, risk/ related factors, subdivided into 12 domains (health promotion, nutrition, elimination and change, activity/rest, perception/ cognition, self-perception, roles and relationships, sexuality, confrontation/endurance to stress, principles of life, safety/ protection and comfort) present in NANDA taxonomy II $^{(8)}$. It is emphasized that the domain, growth/development, was not considered, because the subjects of the study were adults.

In order to verify if the content, appearance, clarity and applicability were adequate to the objective of the research, the tool was analyzed by six infectious nurses, who worked as preceptors in the institution, where the data were collected. For that, the criteria of the punctuation system proposed by Fehring were used. They were also asked to suggest suggestions and modifications considered pertinent. The items that achieved a Concordance Index $\geq 0.80$ among the specialists were considered validated. A pilot test was performed at $10 \%$ of the sampling size. As there was no need for tool changes, the pretest participants were included in the sampling of this study.

Data collection was carried out by four students of Scientific Initiation of the Institutional Program of Scientific Initiation Grants (PIBIC) and supervised by the principal investigator to guarantee methodological rigor. Previous training with the students was carried out to reinforce the use of the tool used in the study, as well as on the topic addressed. The same consisted of a course on Systematization of Nursing Care for people living with AIDS, with a workload of twelve hours. In addition, there was a discussion of the orientation and standardization of the collection procedures, with the purpose of withdrawing doubts and questioning. After the theoretical stage of the training, the practical stage was followed, where the physical examination was performed in pairs. This training had the purpose of enabling students to collect data in a standardized and as homogeneous way as possible. The course was taught by a nurse and coordinated by a teachercounselor of the project.

After the collection, spreadsheets were built, using Microsoft Office Excel software, for the six specialists who participated previously in the validation of the tool. These contained the list of defining characteristics, risk/related factors, ascribed to their presence or absence for each diagnosis investigated, for each user and the researcher of this study. Thus, 100 worksheets, each referring to a user, were prepared as follows: presentation of the patient regarding socio-demographic and clinical data, and listing of investigated ND with the list of diagnostic components. There was also an option, not applicable, which was indicated when the component was not pertinent to the patient, besides the unmeasured option when it was not measurable, as well as pertinent observations related to the characteristics and factors that could direct the inference diagnostic.

The professionals underwent a training provided by the researcher with a view to verifying their diagnostic inference capacity. The objective was to minimize bias at the time of diagnostic inference. To stop so much, the following subjects were approached: the objectives of the research, the method used, clinical reasoning and diagnostic inference, Systematization of Nursing Care and the explanation about operationalization of the inference process of each diagnostician.

After the training, an evaluation was carried out with the six diagnosticians, in order to identify which professionals had greater capacity for diagnostic inference. Twelve clinical cases, involving nursing diagnoses for the twelve NANDA International domains used in the study, were elaborated. In these clinical cases, the clinical history with information pertinent to the diagnostic inference process was narrated, so, from the identification of the signs and symptoms, the diagnostician should indicate the presence or absence of each diagnosis of the domain investigated. The specialists performed the diagnostic inference of the 12 cases, three times, reaching a total of 36 evaluations per specialist.

At the end, the performance of each diagnostician was evaluated using the Kappa test, to verify the agreement between pairs. 
In view of the results obtained, it was observed that the general Kappa coefficients obtained almost perfect agreement for three specialists who were selected as diagnosticians.

When the diagnosticians were listed, they received the 100 worksheets constructed by the researcher, each referring to a patient. Thus, each diagnostician judged in isolation whether the NANDA-I nursing diagnoses, version 2015-2017, were present or absent in each of the sent worksheets. In case of disagreement among the diagnosticians, the majority criterion was applied, which considers the presence of the diagnosis when two or more of them consider it present.

\section{Analysis of results and statistics}

For data analysis, absolute and relative frequencies were used. Fisher's Exact Test and Pearson's Chi-Square were then used to verify the association of NDs, which had a frequency of over $50 \%$ in people living with AIDS, with the following sociodemographic and clinical characteristics: age, gender, marital status, family income, modes of transmission of HIV, existence of other diseases, current opportunistic infection, abandonment of treatment, difficulty in accessing to service, being smoker, alcohol consumer and drug user. The characteristics frequently studied in research involving people living with AIDS $^{(9-15)}$ were used. There was a significance level of $5 \%$.

\section{RESULTS}

The majority of people living with AIDS were male (72\%), were between 30 and 39 years old $(40 \%)$, had no partner $(66 \%)$ and had incomplete primary education (56\%). With regard to family income, a minimum wage income (47\%) predominated. In addition, much of it was resident in the countryside (53\%). Regarding the clinical aspects, the majority reported having been exposed to HIV through intercourse $(97 \%)$, and they had opportunistic infection (70\%).

In terms of treatment, most reported having abandoned treatment $(69 \%)$ and had difficulty accessing the health service $(53 \%)$. According to the research findings, about $51 \%$ of the participants consumed alcohol, $41 \%$ smoked and $31 \%$ reported they have consumed illicit drugs by the week of hospital admission.

Ninety-six nursing diagnoses were identified, with only four prevalent in over $50 \%$ of people living with AIDS, namely: ineffective protection (100\%), poor knowledge (80\%), lack of adherence $(69 \%)$, and sexual dysfunction (54\%). Inadequate protection was present in $100 \%$ of people living with AIDS, a fact that made it impossible to draw up the $2 \times 2$ contingency table between ND, defining characteristics and related factors, thus not allowing the statistical tests of association.

Table 01 shows the analysis of the nursing diagnosis, ineffective protection, with sociodemographic and clinical variables.

Due to the number of NP identified in the study, it was decided to perform the association for those with prevalence greater than or equal to $50 \%$ in people living with AIDS.

With regard to the associations between nursing diagnoses and sociodemographic and clinical characteristics, these are shown in Table 2.
Table 1 - Distribution of nursing diagnosis, ineffective protection, according to sociodemographic and clinical variables in people living with AIDS, Brazil, 2015

\begin{tabular}{|c|c|c|c|}
\hline \multirow{2}{*}{$\begin{array}{c}\text { Clinical and sociodemographic } \\
\text { variables }\end{array}$} & \multicolumn{3}{|c|}{$\begin{array}{l}\text { Nursing Diagnosis: } \\
\text { Ineffective Protection }\end{array}$} \\
\hline & $\begin{array}{c}\text { Present } \\
\%\end{array}$ & $\begin{array}{c}\text { Absent } \\
\%\end{array}$ & $\begin{array}{c}\text { Total } \\
\%\end{array}$ \\
\hline \multicolumn{4}{|l|}{ Age bracket } \\
\hline From 20 to 29 & 17 & 0 & 17 \\
\hline From 30 to 39 & 40 & 0 & 40 \\
\hline From 40 to 49 & 26 & 0 & 26 \\
\hline From 50 to 59 & 14 & 0 & 14 \\
\hline Over 60 & 3 & 0 & 3 \\
\hline Total & 100 & 0 & 100 \\
\hline \multicolumn{4}{|l|}{ Gender } \\
\hline Male & 72 & 0 & 72 \\
\hline Female & 28 & 0 & 28 \\
\hline Total & 100 & 0 & 100 \\
\hline \multicolumn{4}{|l|}{ Marital status } \\
\hline With partner & 66 & 0 & 66 \\
\hline Without partner & 34 & 0 & 34 \\
\hline Total & 100 & 0 & 100 \\
\hline \multicolumn{4}{|l|}{ Place of residence } \\
\hline Countryside & 53 & 0 & 53 \\
\hline Capital & 47 & 0 & 47 \\
\hline Total & 100 & 0 & 100 \\
\hline \multicolumn{4}{|l|}{ Level of schooling } \\
\hline No schooling & 11 & 0 & 11 \\
\hline Incomplete primary education & 56 & 0 & 56 \\
\hline Complete primary education & 12 & 0 & 10 \\
\hline Incomplete high school & 9 & 0 & 11 \\
\hline Complete high school & 7 & 0 & 7 \\
\hline Incomplete higher education & 3 & 0 & 3 \\
\hline Complete higher education & 2 & 0 & 2 \\
\hline Total & 100 & 0 & 100 \\
\hline \multicolumn{4}{|l|}{ Famly income (minimum wages) } \\
\hline Less than 1 & 23 & 0 & 23 \\
\hline 1 & 47 & 0 & 47 \\
\hline 2 & 16 & 0 & 16 \\
\hline 3 & 10 & 0 & 10 \\
\hline 4 & 4 & 0 & 4 \\
\hline Total & 100 & 0 & 100 \\
\hline \multicolumn{4}{|l|}{ Modes of transmission of HIV } \\
\hline Sexual intercourse & 97 & 0 & 97 \\
\hline Blood contact & 3 & 0 & 3 \\
\hline Total & 100 & 0 & 100 \\
\hline \multicolumn{4}{|l|}{ Opportunistic infection } \\
\hline Yes & 70 & 0 & 70 \\
\hline No & 30 & 0 & 30 \\
\hline Total & 100 & 0 & 100 \\
\hline \multicolumn{4}{|l|}{ Abandonment of treatment } \\
\hline Yes & 69 & 0 & 69 \\
\hline No & 31 & 0 & 31 \\
\hline Total & 100 & 0 & 100 \\
\hline \multicolumn{4}{|l|}{ Difficulty of access to service } \\
\hline Yes & 53 & 0 & 53 \\
\hline No & 47 & 0 & 47 \\
\hline Total & 100 & 0 & 100 \\
\hline
\end{tabular}


Table 1 (concluded)

\begin{tabular}{|c|c|c|c|}
\hline \multirow{2}{*}{$\begin{array}{c}\text { Clinical and sociodemographic } \\
\text { variables }\end{array}$} & \multicolumn{3}{|c|}{$\begin{array}{l}\text { Nursing Diagnosis: } \\
\text { Ineffective Protection }\end{array}$} \\
\hline & $\begin{array}{c}\text { Present } \\
\%\end{array}$ & $\begin{array}{c}\text { Absent } \\
\%\end{array}$ & $\begin{array}{c}\text { Total } \\
\%\end{array}$ \\
\hline \multicolumn{4}{|l|}{ Smoker } \\
\hline Yes & 41 & 0 & 41 \\
\hline No & 59 & 0 & 59 \\
\hline Total & 100 & 0 & 100 \\
\hline \multicolumn{4}{|l|}{ Alcohol consumer } \\
\hline Yes & 51 & 0 & 51 \\
\hline No & 49 & 0 & 49 \\
\hline Total & 100 & 0 & 100 \\
\hline \multicolumn{4}{|l|}{ Drug user } \\
\hline Yes & 31 & 0 & 31 \\
\hline No & 69 & 0 & 69 \\
\hline Total & 100 & 0 & 100 \\
\hline
\end{tabular}

Table 2 - Association between Nursing Diagnoses and sociodemographic and clinical characteristics in people living with AIDS, Brazil, 2015

\begin{tabular}{lccc}
\hline \multicolumn{1}{c}{$\begin{array}{c}\text { Sociodemographic and clinical } \\
\text { characteristics }\end{array}$} & $\begin{array}{c}\text { Nursing Diagnosis } \\
\text { Poor } \\
\text { knowledge } \\
(\boldsymbol{p} \text { value) }\end{array}$ & $\begin{array}{c}\text { Lack of } \\
\text { adherence } \\
\text { ( } \boldsymbol{p} \text { value) }\end{array}$ & $\begin{array}{c}\text { Sexual } \\
\text { dysfuction } \\
\text { (p value) }\end{array}$ \\
\hline Age bracket & 0.107 & 0.537 & 0.226 \\
Gender & 0.483 & 0.465 & 0.363 \\
Marital status & 0.441 & 0.446 & $0.013^{*}$ \\
Place of residence & 0.545 & $0.004^{*}$ & 0.749 \\
Level of schooling & $0.002^{*}$ & $0.001^{*}$ & 0.176 \\
Family income & $0.003^{*}$ & $0.020^{*}$ & $0.025^{*}$ \\
Modes of transmission of HIV & $0.001^{*}$ & $0.001^{*}$ & 0.465 \\
Current oportunistic infection & 0.375 & 0.073 & $0.014 *$ \\
Abandonment of treatment & $0.011^{*}$ & $0.001^{*}$ & 0.761 \\
Difficulty of access to the health service & $0.016^{*}$ & $0.011^{*}$ & 0.094 \\
Smoker & 0.123 & 0.082 & 0.692 \\
Alcohol consumer & 0.334 & $0.005^{*}$ & 0.276 \\
Drug user & 0.187 & $0.007^{*}$ & 0.379 \\
\hline
\end{tabular}

Note* Variables that showed significant association

\section{DISCUSSION}

The current epidemiological profile of people living with AIDS in Brazil has been characterized by a higher prevalence of males, who are in the age range between 25 and 39 years, with low purchasing power and residents in the countryside, in a similar way to that found in this study ${ }^{(14)}$.

It is also known that sociodemographic and clinical characterization is a contributory aspect to the construction of nursing diagnoses, since the nurse uses this information to obtain the multidimensional factors on health status, analyzing the determinants and health determinants that individual, family or community ${ }^{(15)}$.

$N D$, ineffective protection, is defined by the decrease in the ability to protect itself from internal or external threats, such as diseases or injuries, characterized in the sample by physical, mental or social changes ${ }^{(8)}$. This ND is an important human response in people living with AIDS, because the pathophysiological alteration caused by the replication of HIV characterized by destruction in the body's defense cells contributes to the appearance of opportunistic infections and coinfections, as well as the abandonment of treatment, since antiretroviral agents act to decrease these viral replications ${ }^{(12)}$.

With regard to ND, ineffective protection, there was a higher frequency among men, aged 30 to 39 years, coming from the state capital, which had no partner and had incomplete primary education. In addition, it predominated in those who presented income from a minimum wage, alcohol users, who had opportunistic infections, reported difficulty accessing the health service, abandoned treatment and exposed themselves to HIV.

A study that investigated the sociodemographic, clinical and behavioral characteristics of men and women living with AIDS identified a higher frequency of opportunistic infections in men, aged between 30 and 39 years old, without partner, with low schooling, low income, who reported abandonment of treatment and alcohol use were more sexually active than women, had more casual partners in the last year, and had a higher HIV exposure behavior due to non-use of condoms ${ }^{(12)}$.

In this sense, some nursing activities should be performed aiming at infection control, namely: monitoring of signs and systemic symptoms and sites of infection, vulnerability to infections and maintenance of precautionary measures. Nursing guidelines related to the importance of the use of antiretroviral agents, as well as how to minimize adverse reactions and avoid complications related to the onset of opportunistic infections are also crucial for therapeutic success.

The second most frequent ND was poor knowledge, which is conceptualized by cognitive deficiency related to a specific topic, and the factors that can corroborate for the spectrum are inability to remember, lack of exposure, interest in learning and opportunity for knowledge ${ }^{(8)}$.

There was a significant association of this ND with the following characteristics: incomplete primary education, minimum wage income, modes of transmission of HIV, abandonment of treatment and difficulty in accessing the service.

Thus, considering that the level of education and family income of the respondents coincide with the social profile of people living with AIDS in Brazil, it affects mainly people with low levels of education or without any type of education, in situations of social impoverishment ${ }^{(2,14)}$.

In this context, researchers point out that the increase in the number of AIDS cases in social strata with lower schooling refers to the poorer coverage of surveillance and care systems among the economically disadvantaged, thus increasing the rate of marital infectivity ${ }^{(14,16)}$. The author also emphasizes that a low level of schooling directly influences the power of discernment and/or decision making, when exposed to risk situations and, consequently, the adoption of self-care to health ${ }^{(17)}$.

Thus, the social characteristics of individuals are contributing factors for the development of signs and symptoms, since economic, educational and other personal and behavioral 
factors influence the way in which the individual acquires and coexists with the disease. Therefore, health education policies must be shared in a homogeneous way.

The need for the nurse to make efforts in order to carry out health education activities aimed at practicing safe sex education; protection against infection from the teaching of signs, and symptoms of infection and ways to prevent infection; procedure/treatment as explained by the purpose and manner of participating in the treatment; and disease process, by explaining the pathophysiology of the disease, its health condition and changes in lifestyle to avoid future complications and/or control of the disease process, as well as measures to control the side effects of treatment of the disease.

It was also identified that the majority of people living with AIDS who presented ND, lack of adherence, resided in the countryside, had incomplete primary education, had a minimum wage income, had sexually exposed to HIV, abandoned treatment, had difficulty access to the service and was an alcohol user.

ND lack of adherence is conceptualized by the behavior of the person and/or caregiver that no longer coincides with a health promotion or therapeutic plan agreed between the person and the health professional( ${ }^{(8)}$. So, negative beliefs related to the disease or treatment, feelings of demotivation or denial of health condition by the individual, resistance or difficulty of behavioral changes and habits of life are part of the individual's value system that make adherence difficult to treat the disease ${ }^{(11)}$.

It is known that the use of antiretroviral agents slows down the accelerated growth of virus infectivity, but continuous and uninterrupted use is necessary to improve the quality of life of people living with AIDS and to reduce the incidence of secondary comorbidities such as pneumonia, tuberculosis and candidiasis. In this sense, health policy interventions should aim not only at the distribution of medication, but at the follow-up of these people at home, building networks of support with Primary Health Care ${ }^{(10)}$.

However, several external factors influence the coping of the disease by people living with AIDS, since the diagnosis has a social impact, which brings stigma either within the family or at the community level(10).

In studies associating the social characteristics of people living with AIDS with clinical aspects, they identified that many had a low level of schooling and abandoned treatment due to interpersonal factors, such as adverse reactions caused by antiretroviral therapy ${ }^{(16,18)}$. One of the studies also added that most of the participants came from the countryside, had incomplete primary education, were exposed to HIV through intercourse and abandoned treatment, thus contributed to the construction of diagnostic inference ${ }^{(18)}$.

Authors further point out that the financial income of people living with AIDS influences their health care needs, because the higher the income, the more accessibility to health surveillance and the better the condition, in other words, there is a triad of better income, better health status and lower incidence of comorbidities ${ }^{(16,18)}$.

The use of alcohol and other drugs are among the main factors leading to abandonment of treatment. However, researchers in Belgium identified that 78.55 to $93.5 \%$ of the survey participants were smokers, who reported that alcohol and tobacco were not grounds for dropping out of treatment, but were interpersonal conflicts, and the stigma of the disease $\mathrm{e}^{(13)}$.
In this way, some of the nursing activities deserve attention in order to modify the adherence behavior, namely: to determine the users' motivation to change, to help them to identify strengths and to reinforce them, to encourage the substitution of undesirable habits for desirable ones, and to discuss with important people/user in the process of behavior modification.

Finally, ND, sexual dysfunction, conceptualized as the limitations imposed by the disease and therapy and the inability to achieve the desired satisfaction ${ }^{(8)}$, showed a significant association with marital status, income and opportunistic infections. The research pointed out that of people living with AIDS, most had several partners, had a minimum wage income and had opportunistic infections, such as streptococcal gonorrhea(13).

Fear of transmission and bias contributes to the distancing of people living with AIDS from marital relations with others ${ }^{(19)}$.

Some people living with AIDS may have common characteristics, such as the actual limitations imposed by the disease, and the onset of diseases in the genital area, such as gonorrhea, syphilis, and venereal granuloma. Other contributory factors for sexual dysfunction are the use of antiretroviral therapy and opportunistic infections that may lead to changes in hormone production, causing a decrease in testosterone and estrogen and, consequently, decreased libido and cessation or reduction of sexual activity ${ }^{(20)}$.

Therefore, it is necessary for the nurse to take actions aimed at advising users on the sexual aspects, informing them that sickness, medications and stress usually change the sexual function, encouraging them to verbalize fears and ask questions, seeking to include the sexual partner, as appropriate.

\section{Study limitations}

As a limitation of this study, it is pointed out the bias of memory of some interviewees regarding some information related to the diagnosis and treatment of the disease.

\section{Contributions to the sectors of nursing, health or public policy}

The associations identified in this study are presented as a contribution to the practice of Nursing in the most qualified care to people living with AIDS, since they allowed the analysis of the human responses of these individuals in function of their socioeconomic and clinical conditions, providing a better focus of care directed to the needs of this clientele. Based on this analysis, nurses should pay attention to the social needs of people living with AIDS in planning their care, respecting the individual aspects of each client, and eliminating or minimizing human responses in this population. Finally, the results found here may contribute to the advances and the incorporation of a universal language in the description of professional practice, in favor of improving the quality of Nursing care in the national setting, respecting the integrity of the human being and contributing to the strengthening nursing as a science.

\section{CONCLUSION}

It was evidenced that the majority of people living with AIDS were male, aged between 30 and 39 years, had no partner, resided in the countryside and had incomplete primary education and low wage income. As for clinical aspects, most 
had an opportunistic infection and reported having abandoned treatment, as well as being exposed to the HIV virus through intercourse.

After analyzing the data, it was observed that the main sociodemographic and clinical characteristics that showed a significant statistical association with the identified ND were: marital status, place of residence, schooling level, family income, modes of transmission of acquired immunodeficiency virus, current opportunistic infection, abandonment of treatment, difficulty in accessing health services, and use of alcohol and illicit drugs.

The study allowed associating the sociodemographic and clinical predisposing factors to the nursing diagnoses, which could determine the clarity and assertiveness of the nursing interventions aiming to achieve positive results.

\section{REFERENCES}

1. UNAIDS. Joint United Nations Programm on HIV/AIDS. AIDS by the numbers[Internet]. 2016 [cited 2017 May 02]. 28p. Available from: http://www.unaids.org/en/resources/documents/2016/AIDS-by-the-numbers

2. Brasil. Ministério da Saúde. Coordenação Nacional DST/Aids. Vigilância Epidemiológica. Boletim Epidemiológico de Aids[Internet]. Brasília: MS; 2016 [cited 2017 May 02]. 64p. Available from: http://www.aids.gov.br/sites/default/files/anexos/publicacao/2016/59291/ boletim_2016_1_pdf_16375.pdf

3. Gómez EJ, Harris J. Political repression, civil society and the politics of responding to AIDS in the BRICS nations. Health Policy Plan [Internet]. 2016 [cited 2017 May 02];31(1):56-66. Available from: https://academic.oup.com/heapol/article-lookup/doi/10.1093/ heapol/czv021

4. Yang OO, Cumberland WG, Escobar R, Liao D, Chew KW. Demographics and natural history of HIV-1-infected spontaneous controllers of viremia. J Int AIDS Soc[Internet]. 2017[cited 2017 May 02];31(8):1091-8. Available from: http://insights.ovid.com/cr ossref?an =00002030-201705150-00005

5. Frazão CMFQ, Tinôco JDS, Paiva MGMN, Lira ALBC, Lopes MVO, Enders BC. Association between nursing diagnoses and socieconomic/clinical characteristics of patients on hemodialysis. Int J Nurs Knowl[Internet]. 2015[cited 2017 May 04];26(3):1-6. Available from: http://onlinelibrary.wiley.com/doi/10.1111/2047-3095.12051/epdf

6. Frazão CMFQ, Tinôco JDS, Medeiros ABA, Fernandes MICD, Lira ALBC, Lopes MVO. The adaptation problems of patients undergoing hemodialysis socioeconomic and clinical aspects. Rev Latino-Am Enfermagem [Internet]. 2014[cited 2017 May 04];22(6):966-72. Available from: http://www.scielo.br/pdf/rlae/v22n6/0104-1169-rlae-22-06-00966.pdf

7. Fernandes MICD, Soares CS, Tinôco JDS, Delgado MF, Paiva MGMN, Lopes MVO, et al. Excess fluid volume: sociodemographic and clinical analysis in Hemodialysis in patients. Rev Bras Enferm[Internet]. 2017[cited 2017 May 05];70(1):15-21. Available from: http://www.scielo.br/pdf/reben/v70n1/0034-7167-reben-70-01-0015.pdf

8. Herdman TH, Kamitsuru. Diagnósticos de Enfermagem da NANDA: definições e classificação - 2015/2017. $2^{a}$ ed. Porto Alegre: Artmed; 2015.

9. Souza NVL, Andrade LL, Agra G, Costa MML, Silva RAR. Profile of nursing diagnoses of hospitalized patients in an infectious disease unit. Rev Gaúcha Enferm[Internet]. 2015[cited 2017 May 15];36(3):79-85. Available from: http://www.scielo.br/pdf/rgenf/ v36n3/1983-1447-rgenf-36-03-00079.pdf

10. Souza GO, Tibúrcio AACM, KOIKE MK. Appropriate adherence to antiretroviral therapy in the Alto Paranaiba, Minas Gerais, Brazil. Med Express [Internet]. 2016 [cited 2017 May 15];3(3):1-7. Available from: http://www.scielo.br/pdf/medical/v3n3/23188111-medical-03-03-20160305.pdf

11. Wohl DA, Panter AT, Kirby C, Magnus BE, Hudgens MG, Allmon AG, et al. Estimating HIV medication adherence and persistence: two instruments for clinical and research use. AIDS Behav [Internet]. 2017 [cited 2017 May 15];1-13. Available from: https://www.researchgate. net/publication/316498495_Estimating_HIV_Medication_Adherence_and_Persistence_Two_Instruments_for_Clinical_and_Research_Use

12. Senard O, Burdet C, Visseaux B, Charpentier C, Le Gac S, Julia Z, et al. Epidemiological profile of newly diagnosed HIV-infected patients in Northern Paris: a retrospective study. AIDS Res Hum Retroviruses[Internet]. 2017[cited 2017 May 20];33(1):11-6. Available from: https://www.ncbi.nlm.nih.gov/pubmed/27476681/

13. Degroote S, Vogelaers D, Vermeir P, Mariman A, Gucht BVD, Pelgrom J, et. al. Determinants of adherence in a cohort of Belgian HIV patients: a pilot study. Acta Clin Belg[Internet]. 2014[cited 2017 May 20]; 69(2):111-5. Available from: https://www.ncbi.nlm. nih.gov/pubmed/24724750

14. Silva RAR, Fernandes ER, Sousa Neto VL, Rodrigues IDCV, Andrade IFC, Silva BCO, et. al. Prevalence of the nursing diagnosis lack of adherence in people living with AIDS. O J Nurs[Internet]. 2016[cited 2017 May 20];(6):386-95. Available from: http://file. scirp.org/pdf/OJN 2016051215220875.pdf

15. Tastan S, Linch GC, Keenan GM, Stifter J, McKinney D, Fahey L. et al. Evidence for the existing American Nursing Associationrecognized standardized nursing terminologies: a systematic review. Int J Nurs Stud[Internet]. 2014[cited 2017 May 20];51(8):116070. Available from: http://www.journalofnursingstudies.com/articleS0020-7489\%2813\%2900381-7/pdf

16. Silva JAG, Dourado I, Brito AM, Silva CAL. Factors associated with non-adherence to antiretroviral therapy in adults with AIDS in 
the first six months of treatment in Salvador, Bahia State, Brazil. Cad Saúde Pública[Internet]. 2015[cited 2017 May 20];31(6):1-11. Available from: http://www.scielo.br/pdf/csp/v31n6/en_0102-311X-csp-31-6-1188.pdf

17. Costa RHS, Nelson ARC, Prado NCC, Rodrigues EHF, Silva RAR. Nursing diagnoses and their components in acquired immune deficiency syndrome patients. Acta Paul Enferm[Internet]. 2016[cited 2017 May 20];29(2):146-53. Available from: http://www. scielo.br/pdf/ape/v29n2/en_1982-0194-ape-29-02-0146.pdf

18. Santos VF, Galvão MTG, Cunha GH, Lima ICV, Gir E. Alcohol effect on HIV-positive individuals: treatment and quality of life. Acta Paul Enferm [Internet]. 2017 [cited 2017 May 20];30(1):94-100. Available from: http://www.scielo.br/pdf/ape/v30n1/en_19820194-ape-30-01-0094.pdf

19. Silva RAR, Costa RHS, Nelson ARC, Duarte FHS, Prado NCC, Rodrigues EHF. Predictive factors for the nursing diagnoses in people living with Acquired Immune Deficiency Syndrome. Rev Latino-Am Enfermagem[Internet]. 2016[cited 2017 May 20];24:e2712. Available from: http://www.scielo.br/pdf/rlae/v24/0104-1169-rlae-24-02712.pdf

20. Romero-Velez G, Lisker-Cervantes A, Villeda-Sandoval CI, Zavaleta MS, Olvera-Posada D, Sierra-Madero JG, et al. Erectile dysfunction among HIV patients undergoing highly active antiretroviral therapy: dyslipidemia as a main risk factor. J Sex Med [Internet]. 2014 [cited 2017 May 20];2:24-30. Available from: https://www.ncbi.nlm.nih.gov/pmc/articles/PMC4184613/pdf/sm20002-0024.pdf 